\title{
Sensitivity of the CMIP5 models to precipitation in Tropical Brazil
}

The main objective of this study is to evaluate the ability of the fifth phase of the Coupled Model Intercomparison Project (CMIP5) models to simulate weekly rainfall over Tropical Brazil. Twenty-four years of the historical experiment of sixteen models for the austral summer and fall seasons were evaluated. In the analyzes performed in this study, frequency distribution and correlation were used to evaluate temporal variability. Principal Component Analysis to ascertain the characteristics of the dominant pattern of each model. The results suggest that some models have difficulty in simulating the spatial pattern of regional precipitation, especially related to the frequency of events and temporal variation, however, the dominant pattern found by the Principal Component Analysis showed that at least six models (ACCESS1-0, CanESM2, EC-EARTH, GFDL-CM3, MIROC5 and MRI-CGCM3) reasonably represented the temporal-space precipitation regime over Tropical Brazil.

Keywords: Climatic Change; Historical Period; Rainfall.

\section{Sensibilidade dos modelos CMIP5 à precipitação no Brasil Tropical}

O objetivo principal deste estudo é avaliar a capacidade da quinta fase dos modelos do Coupled Model Intercomparison Project (CMIP5) em simular chuvas semanais sobre o Brasil Tropical. Vinte e quatro anos do experimento histórico de dezesseis modelos para as estações do verão e outono austral foram avaliados. Nas análises realizadas neste estudo, a distribuição de frequência e a correlação foram utilizadas para avaliar a variabilidade temporal. Análise de componentes principais para verificar as características do padrão dominante de cada modelo. Os resultados sugerem que alguns modelos apresentam dificuldade em simular o padrão espacial de precipitação regional, principalmente em relação à frequência de eventos e variação temporal, porém, o padrão dominante encontrado pela Análise de Componentes Principais mostrou que pelo menos seis modelos (ACCESS1-0, CanESM2, EC-EARTH, GFDL-CM3, MIROC5 e MRI-CGCM3) representaram razoavelmente o regime de precipitação no espaço temporal sobre o Brasil Tropical.

Palavras-chave: Mudança climática; Período histórico; Precipitação.

Topic: Meteorologia, Climatologia e Mudanças Climáticas

Reviewed anonymously in the process of blind peer.
Received: 01/01/2021

Approved: 26/01/2021
Naurinete de Jesus da Costa Barreto ib

Instituto Nacional de Pesquisas Espaciais, Brasil

http://lattes.cnpq.br/9415435965900811

http://orcid.org/0000-0001-5167-6228

netebarreto@gmail.com

\section{David Mendes}

Universidade Federal do Rio Grande do Norte, Brasil

http://lattes.cnpq.br/4411895644401494

davidmendes@ccet.ufrn.br

\section{Paulo Sérgio Lucio}

Universidade Federal do Rio Grande do Norte, Brasil

http://lattes.cnpq.br/5291232352923880

pslucio@ccet.ufrn.br

\section{Referencing this:}

BARRETO, N. J. C.; MENDES, D.; LUCIO, P. S.. Sensitivity of the CMIP5 models to precipitation in Tropical Brazil. Revista Ibero Americana de Ciências Ambientais, v.12, n.1, p.180-191, 2021. DOI: http://doi.org/10.6008/CBPC2179-6858.2021.001.0015 


\section{INTRODUCTION}

In Tropical Brazil (TBr), the rainy season starts in the austral summer (December-January-February) and lasts until the austral autumn (March-April-May), presenting a high spatial-temporal variability and high probability of occurrence extreme events (RAO et al., 1990). In some places, precipitation during the austral autumn corresponds to $35 \%$ of the yearly total, while in others it can exceed 50\% (SOUZA et al., 2004).

The area under study included two large contrasting regions: the Northeast of Brazil (NEB), which has significant limitations regarding the use of its natural resources because of the low rainfall and the substantial variations in total precipitation, making it one of the most vulnerable regions of Brazil to climatic changes in the precipitation regime (KOUADIO et al., 2012; KROL et al., 2007; OYAMA et al., 2004) and the Amazon (AMZ), on the other hand, has intense rainfall throughout the year and its hydrological cycle is of great importance for the regional and global climatic equilibrium. In addition, the main biome of the region is classified as tropical forest, answering for approximately $15 \%$ of the planet's photosynthesis (COX et al., 2004; FIELD et al., 1998; MARENGO, 2004). The strong variability in the rainfall regime of the AMZ is therefore directly related to changes in the hydrological parameters of the Amazon river (MARENGO et al., 2008), as well as with changes related to vegetation, such as the stomatal aperture of plants due to increases in temperature, which may contribute to the local reduction of rainfall (COX et al., 2004).

Because of the fragility of these ecosystems, natural, physical and biological processes can be influenced by climate change, whether these are natural or caused by increases in greenhouse gasses (GONZALEZ et al., 2007; MARENGO et al., 2007). These changes are assessed by the project CMIP5, which is conducted by several international climate research groups to assess the performance of climate simulation models in relation to the current climate and the projections made until the end of the 21st century (TAYLOR, 2008). Compared to the previous version (CMIP3), CMIP5 has a better atmospheric and oceanic spatial resolution, in addition to a more representative model of the dynamics and-chemical processes of the atmosphere (SABEERALI et al., 2013).

Studies that cover the northern sector of South America have shown that the CMIP3 models have difficulty in representing the intermediate seasons, mesoscale phenomena and local atmospheric circulation effects. In addition, they underestimate annual means, especially in AMZ, despite the fact of the standard deviation of the wet season being closer to observed values (LI et al., 2006; SILVEIRA et al., 2012; SILVEIRA et al., 2013; VERA et al., 2006). In the first assessments related to CMIP5, the models were able to consistently represent the annual cycle and the interannual variations, but the decadal signal had low representativeness, especially over the Northeast of Brazil (SILVEIRA et al., 2013).

The temporal variability of the total accumulated precipitation in $\mathrm{TBr}$, on the weekly and monthly scale, has been evaluated by Barreto et al. (2013a; 2013b). They concluded that some models are better at characterizing dry and rainy periods, but present discrepancies in the intermediate seasons, i.e. the pre-rainy and pre-dry seasons. Studies that assessed the sensitivity to seasonal rainfall over TBr captured by the CMIP5 models, with this in mind the main objective of this study is to demonstrate the ability of the models that 
make up the CMIP5 to represent the simulated rainfall for the period from December to May. In addition, the models ability to predict the frequency distribution of precipitation events is assessed, identifying those capable of showing the dominant precipitation pattern during the rainy season of the region. Specifically, we sought to answer the following questions: 1 . What is the sensitivity of the CMIP5 models in relation to the classes of precipitation and the observed-values in TBr?; 2 . What is the spatial variability pattern from December to May over TBr?; 3. How many models are capable of representing the spatial-temporal pattern of rainfall over Tropical Brazil in the months of December to May?

\section{MATERIALS AND METHODS}

\section{Database}

To assess the sensitivity of the climate simulation models to regional patterns over $\mathrm{TBr}$, six regions were selected, used by Barreto et al. (2013b), which are presented in Table 1. The data used in this study concern daily precipitation by grid point, covering the perıod from January 1979 to December 2004. The information was obtained from the database of the Climate Prediction Center unified gauge (CPC-uni). CPCuni uses an interpolation method that re-projects point precipitation on to a grid (CHEN et al., 2008; SILVA et al., 2011).

Table 1: Location of the studied regions.

\begin{tabular}{l|l|l}
\hline Região & Sigla & Coordenadas Geográficas \\
\hline Southwest Amazon & SWAM & $73.25^{\circ} \mathrm{W}-59.50^{\circ} \mathrm{W}, 12.5^{\circ} \mathrm{S}-3.75^{\circ} \mathrm{S}$ \\
\hline Southeast Amazon & SEAM & $59.25^{\circ} \mathrm{W}-45.00^{\circ} \mathrm{W}, 12.5^{\circ} \mathrm{S}-3.75^{\circ} \mathrm{S}$ \\
\hline Northwest Amazon & NWAM & $73.25^{\circ} \mathrm{W}-59.5^{\circ} \mathrm{W}, 3.75^{\circ} \mathrm{S}-5.00^{\circ} \mathrm{S}$ \\
\hline Northeast Amazon & NEAM & $59.00^{\circ} \mathrm{W}-45.00^{\circ} \mathrm{W}, 3.75^{\circ} \mathrm{S}-5.00^{\circ} \mathrm{S}$ \\
\hline North of Northeast Brazil & NNEB & $45.25^{\circ} \mathrm{W}-34.50^{\circ} \mathrm{W}, 10.00^{\circ} \mathrm{S}-2.00^{\circ} \mathrm{S}$ \\
\hline South of Northeast Brazil & SNEB & $45.25^{\circ} \mathrm{W}-34.5^{\circ} \mathrm{W}, 18^{\circ} \mathrm{S}-10^{\circ} \mathrm{S}$ \\
\hline
\end{tabular}

The observed precipitation was compared with the simulated precipitation of sixteen models included in the CMIP5 project, which are laid out in Table 2, considering the Historical (1981-2005) experiment, representing the current climate in conjunction with the compositions of observed atmospheric changes and other forcing agents, such as greenhouse gases, aerosols, natural changes, and volcanic and solar activity (TAYLOR et al., 2012). The CMIP5 data are the result of simulations by the global models of some research centers, forced by the greenhouse gases observed during the 20th century. In this study, we used only data related to configuration r1i1p1.

Table 2: Available CMIP5 models and horizontal resolution.

\begin{tabular}{lll}
\hline Model & Modeling Center & Horizontal Resolution \\
\hline ACCESS1.0 & CSIRO - BOM, Austrália & $192 \times 145$ \\
CanESM2 & CCCma, Canada & $128 \times 64$ \\
CCSM4 & NCAR, USA & $288 \times 192$ \\
CNRM-CM5 & CNRM - CERFACS, France & $256 \times 128$ \\
CSIRO-Mk3.6.0 & CSIRO - QCCCE, Australia & $192 \times 96$ \\
EC-EARTH & EC-Earth & $320 \times 160$ \\
GFDL-CM3 & NOAA GFDL & $144 \times 90$ \\
GFDL-ESM2M & NOAA GFDL & $144 \times 90$ \\
HadGEM2-ES & Met Office Hadley Centre, UK & $192 \times 145$ \\
\hline
\end{tabular}




\begin{tabular}{lll}
\hline INM-CM4 & INM, Russia & $180 \times 120$ \\
IPSL-CM5A-LR & IPSL, France & $96 \times 96$ \\
MIROC5 & AORI - NIES - JAMSTEC, Japan & $256 \times 128$ \\
MIROC-ESM & AORI - NIES - JAMSTEC, Japan & $256 \times 128$ \\
MPI-ESM-LR & Max Planck Institute for Meteorology & $192 \times 96$ \\
MRI-CGCM3 & MRI, Japan & $320 \times 160$ \\
NorESM1-M & Norwegian Climate Centre & $144 \times 96$ \\
\hline
\end{tabular}

\section{Histogram}

Histogram is a graphical representation, the purpose of which is to count the number of observations contained in a given class interval. Then, considering the total number of observations and the total number of class intervals, the histogram must satisfy the following condition.

$$
N=\sum_{i=1}^{k} m_{i}
$$

\section{Taylor's Diagram}

The Taylor diagram provides a summary graphical view of some metrics used to assess the degree of similarity between data sets, considering a reference set. These diagrams are especially useful in evaluating multiple aspects of complex models or in assessing the relative ability of many different models.

Given a field $(f)$ and a reference field $(r)$, the formulas for calculating the correlation coefficient $(R)$, the centered RMS difference $\left(E^{\prime}\right)$ and the standard deviations of the field $(f)$ and the reference field $(r)$ is given below:

$$
\begin{gathered}
R=\frac{\frac{1}{N} \sum_{n=1}^{n}\left(f_{n}-\bar{f}\right)\left(r_{n}-\bar{r}\right)}{\sigma_{f} \sigma_{r}} \\
E^{\prime 2}=\frac{1}{N} \sum_{n=1}^{N}\left[\left(f_{n}-\bar{f}\right)\left(r_{n}-\bar{r}\right)\right]^{2} \\
\sigma_{f}=\frac{1}{N} \sum_{n=1}^{N}\left(f_{n}-\bar{f}\right)^{2}
\end{gathered}
$$

\section{Principal Component Analysis}

The dominant pattern of rainfall variability over the $\mathrm{TBr}$ was determined using the Principal Components Analysis (PCA), applied to weekly precipitation anomalies, for 26 seasons (years) of summer and southern autumn for the years 1979-1980 until 2004-2005, in the 16 models of climatic simulation of CMIP5 and the observed data from CPC-uni.

PCA is one of the most used multivariate statistical techniques today, consisting of a way to transform a set of dimensional $N$ - vectors of correlated observations into another set of unrelated dimensional $N-$ vectors. In summary, the original data is basically projected on new coordinate axes, to achieve a reduction of data and its dimensionality, maintaining its fundamental modes of variance (PEÑARROCHA et al., 2002).

Considering that the matrix $Z$ is the matrix of the observed data, containing $m$ grid points and $n$ times, 
a correlation matrix is obtained, given by:

$$
\boldsymbol{R}=\frac{1}{(\boldsymbol{n}-\mathbf{1})}(Z)(Z)^{t}
$$

$Z_{t}$ being the transposed matrix of $Z$, and $R$ is a positive symmetric matrix of dimension $(k x k)$, it is diagonalizable by a matrix $A$, following the equation below:

$$
D=A^{-1} \cdot R \cdot A
$$

Where $D$ is the diagonal matrix, whose elements are the eigenvalues of $a_{j i}$. It is possible to obtain linear combinations by multiplying matrix $A$ by the matrix of observations $Z$, that is:

$$
U=A^{t} X
$$

The solution to this equation is unique and considers the total variation present in the set of initial variables. Creating a new set of uncorrelated variables, with each variable explaining a decreasing percentage of the original variance, that is, it explains a greater proportion of the variance than a and so on (WILKS, 2011).

The relationships between the variables that contribute significantly to Principal Components (PC) are used as a basis for the interpretation of physical, climatic and other processes. The use of the correlation matrix, instead of the covariance matrix of all variables, means that at the level of future comparisons, information on the internal variability of the original set will not be necessary to compare with other sets of interest (MALMGREN et al., 1999). In this study the first two components are selected, the eigenvectors for each model are compared with the eigenvectors of the observed data, and the main components are correlated with the components of the observed data.

\section{RESULTS}

\section{Frequency of Classes}

The rainfall frequency distribution over the six regions of $\mathrm{TBr}$ is represented by gray bars in Fig. 1 . The most intense frequencies can be observed in the regions that represent the AMZ (Fig. 1a-d), with

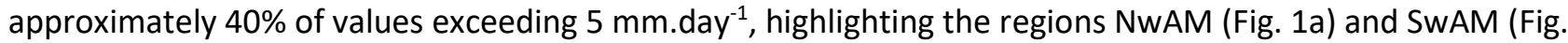
1c), which have around $20 \%$ of the events with more than $10 \mathrm{~mm}$.day ${ }^{-1}$. In NEB (Fig. 1e-f), however, the precipitation of the season consists mostly of events with less than $5 \mathrm{~m} \cdot$ day $^{-1}$, covering nearly $80 \%$ of weekly precipitation events.

The Fig. 1a shows the precipitation frequency distribution for NwAM. This region has an intense rainfall regime with little variation over time. The models that best represented this regime were: CANESM2M, MIROC5, CNRMCM5, HaqdGEM2M, MPI-ESM, NorESM1M, overestimating the precipitation below 5 mm.Day ${ }^{-1}$ by little more than $15 \%$. The rainfall regime of SwAM was best represented by the ECEARTH, MIROC, GFDL-ESM and INMCM4 models. The models IPSL-CM and MIROC5 overestimated the events with less than $5 \mathrm{~mm}^{\text {day }}{ }^{-1}$ by approximately $20 \%$, the other models by more than $35 \%$, especially the events with very weak rain $<5 \mathrm{~mm}$.day ${ }^{-1}$ and light rain between $5 \mathrm{~mm}^{\text {day }}{ }^{-1}$ and $10 \mathrm{~mm} \cdot$ day $^{-1}$ (Fig. 1b).

The NeAM region (Fig. 1C) features most models overestimated the quantity of light rain events. The 
model CSIRO-mk3 over estimated this category of precipitation by $60 \%$, while the models MPI-ESM, ACCESS10, IPSL-LR, MRI-CGCM3, CCSM4, GFDL-ESM2M and GFDL-CM3 overestimated it by about 25\%. The MIROC, MIROC-ESM, HadGEM2M, CanESM2M and NorESM1M models show a frequency close to the one observed with differences below $10 \%$ for very weak events, it's interesting that in this region the models EC-EARTH, CNRCM5 and INMCM4 underestimated weak rainfall by $25 \%$ and overestimated rainfall between $5 \mathrm{~mm}^{\text {d day }}{ }^{-1}$ and $15 \mathrm{~mm}$.day ${ }^{-1}$ (Fig. 1c). The EC-EARTH, MIROC-ESM, CCSM4, MPI-ESM, CNRMCM5 and HadGEM2M models showed more realistic results for SeAM, but ACCESS1-0 and CSIRO overestimated very weak rains by $40 \%$, and MRI-CGCM3 overestimated rains between $5 \mathrm{~mm} \cdot$ day $^{-1}$ and $15 \mathrm{~mm} \cdot$ day $^{-1}$ by $30 \%$. The other models underestimated rainfall below $5 \mathrm{~mm}$.day ${ }^{-1}$ by $20 \%$ (Fig. $1 \mathrm{~d}$ ).

The regions that make up the Northeast of Brazil (NNEB and SNEB), Fig. 1e and Fig. 1f, also revealed differences in the sensitivity of models, especially in NNEB. In this region, most models underestimate weak to very weak precipitation, between 77\% for INMCM4 and 35\% for the models CCSM4, EC-EARTH, MIROCESM, ACCESS1-0, IPSL-LR, MIROC and MPI-ESM, and they overestimate rainfall in excess of $10 \mathrm{~mm}$. The models CSIRO-mk3, CNRMCM5 and HADGEM2M stayed closest to the observed values with a difference of 20\%. In SNEB (Fig. 1f), the MIROC, MIROC-ESM, CNRMCM5 and HADGEM2M models were the ones that best represented the rainfall frequencies. The relations between the models are quite diverse, some overestimate values below $5 \mathrm{~mm} \cdot$ day $^{-1}$.

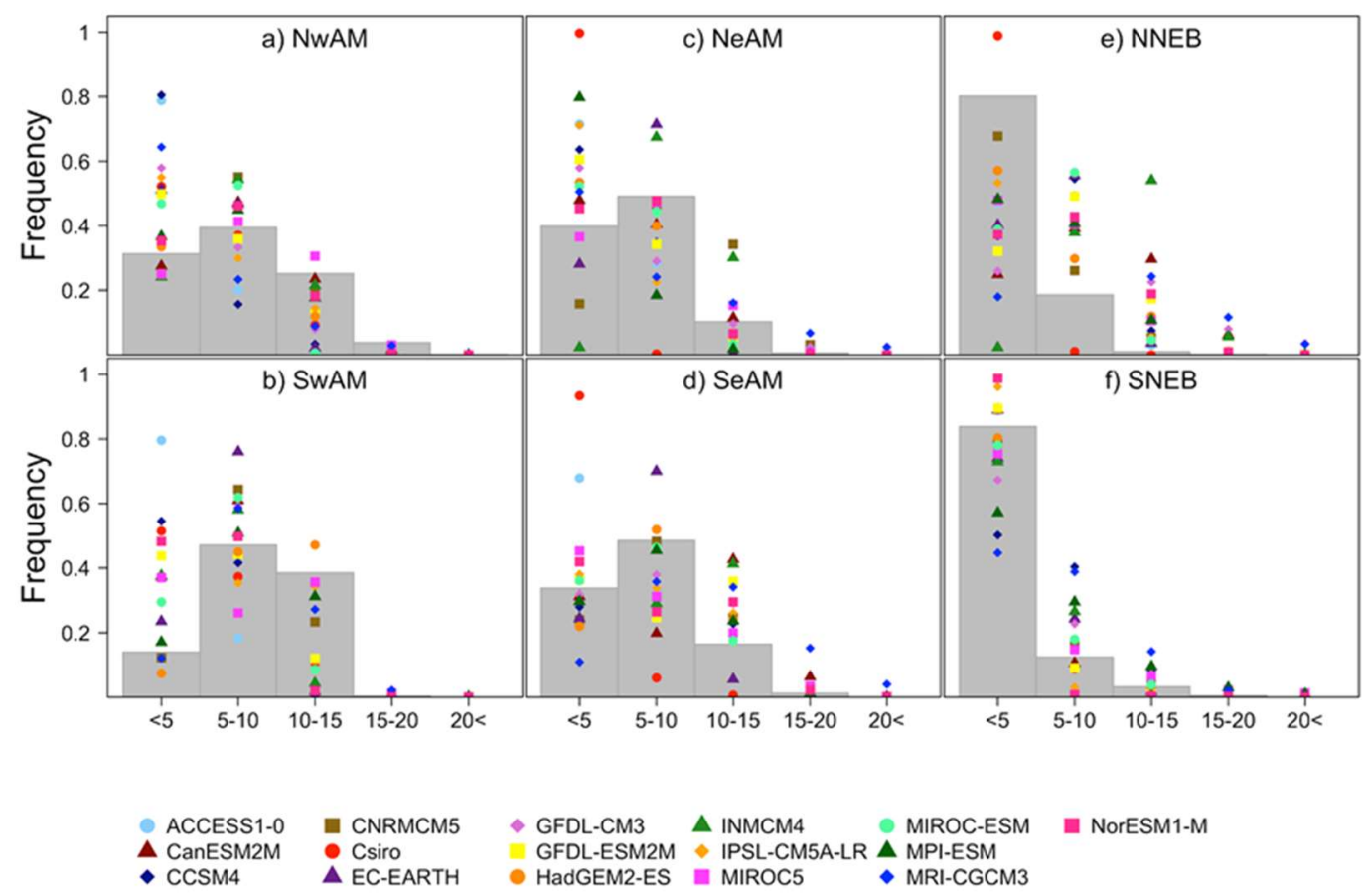

Figure 1: Frequency distribution of precipitation classes for the selected regions. Gray bars represent the data from CPC-uni, dots are the CMIP5 models.

The Taylor diagram is used to objectively evaluate the ability of models to simulate the weekly rainfall time series in the austral summer and autumn for the six regions of $\mathrm{TBr}$ (Fig. 2). To assess this diagram we used the same criteria as (SABEERALI et al., 2013), where significant values were those with correlations above 0.75 and a normalized standard deviation between 0.5 and 1.5. In general, the models were better in 
representing the rainfall regime over the southern Amazon (SeAM, SwAM). These regions had correlations between 0.5 and 0.7 and a standard deviation ration close to 1.0. In the north of the Amazon (NwAM and NeAM) the ratio between the deviations varied between 0.5 and 1.0, but the correlation in NeAM is less than 0.5 , and in NwAM it varies between 0.4 and 0.7. The regions that make up NEB show the lowest sensitivity values and a high dispersion between models. The ratio between deviations ranged between 0.5 and 2.5 and the correlations were less than 0.4 in all models. In this evaluation, the model INMCM4 stood out with a high ratio between deviations and very low correlations in all regions, with the exception of SeAM.

Regarding the sensitivity of the models to the representation of the variability of precipitation during the southern summer and autumn, it is possible to observe that models ACCESS1-0, MIROC-ESM, CanESM2M, INMCM4, IPSL-CM5A-LR, showed a 0.65 correlation for the Amazon and 0.27 for the Northeast, while the models EC-EARTH, GFDL-CM3, GFDL-ESM2M, NorESM1-M, MIROC5, MPI-ESM, present a correlation of 0.6 and 0.22 for the Amazon and Northeast Brazil, respectively. The CCSM4 MRI-CGCM3 models had a correlation of 0.4 for the Amazon and 0.16 for the Northeast, and the models that show low sensitivity to the $\mathrm{TBr}$ precipitation signal are CNRMCM5, Csiro, HadGEM2-ES, for these models the correlation for the Amazon was 0.3 and for the Northeast of Brazil of 0.10
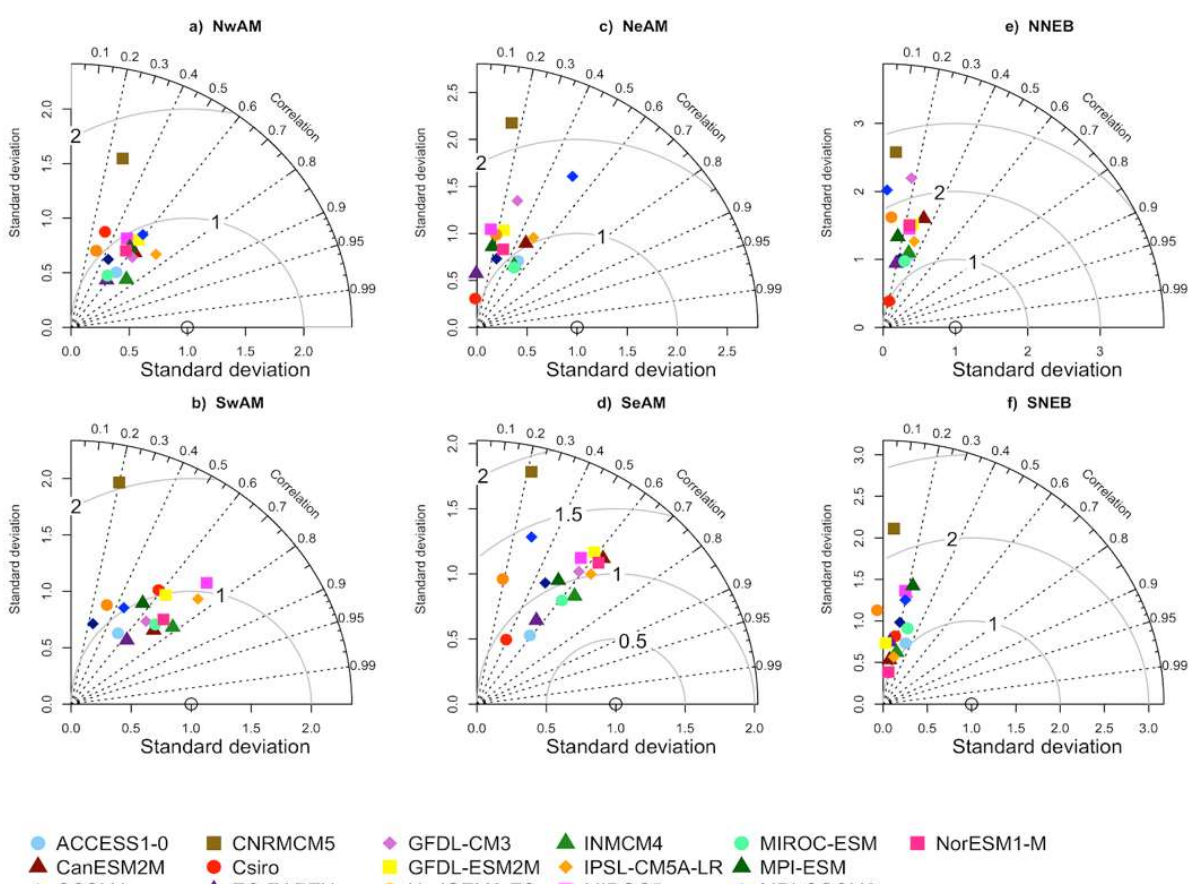

- CCSM4

EC-EARTH

CM5A-LR $\triangle$ MPI-ESM

HadGEM2-ES MIROC5

Figure 2: Taylor diagram of the selected regions of $\mathrm{TBr}$ for weekly mean precipitation for the period from December to May.

\section{Spatial Variability}

The spatial variability of precipitation observed during the months of Dec-May is presented in Fig. 3, the dominant pattern of the first component is characterized by a large area covering the southern Amazon and a great part of the NEB with significant predominance of high values. One can see that the signal in the northernmost part of South America is negative, indicating that systems that intensify precipitation in the 
remainder of $\mathrm{TBr}$, generally inhibit rains at the far north of South America. Given that the PCA was applied to a non-filtered set of precipitation, the pattern found was consistent with those obtained in other studies (CARVALHO et al., 2013; SOUZA et al., 2006). The spatial pattern of the second component shows a pattern with an intense nucleus between the north and northeast sectors of the TBr and a softer one with an opposite sign over the southern region of the $\operatorname{TBr}$ (Fig. 3b). The anomalous pattern of precipitation in the north and east of the NEB is heterogeneous, this pattern is consistent with the analysis carried out by Souza et al. (2006) e Barreto et al. (2017).

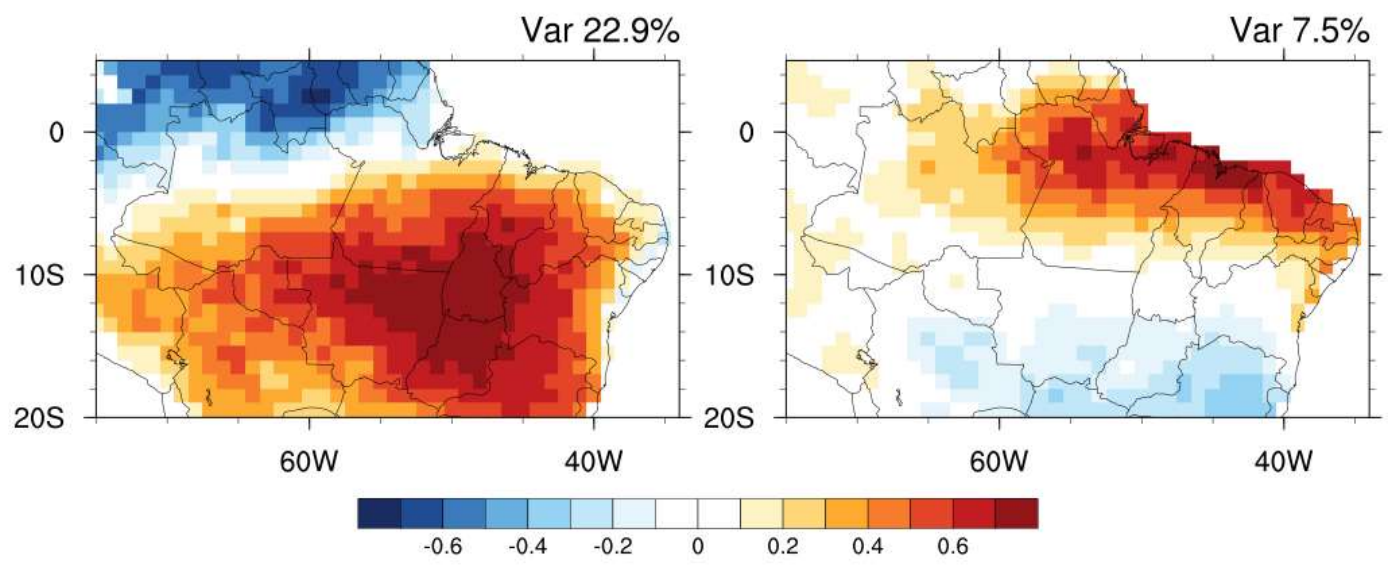

Figure 3: Correlation coefficient between PC1 (PC2) and the observed CPC-uni precipitation, panel on the left (panel on the right) for the months of December to May, on the $\mathrm{TBr}$.

Table 3 shows the percentage of variance captured by the first two components of the CMIP5 models and the correlation coefficient between the Scores of the components of observed data and the components of the models. With respect to the captured variance, one can see that most of the models have values between $25 \%$ and $36 \%$ of variance in relation to the first component, with the model NorESM1M with the highest percentage of $36 \%$ and the EC-EARTH with the lowest of $9.3 \%$, in relation to the PC1 the observed data has a variance of $22.9 \%$. The second component has a captured variance of $7.5 \%$ in the observed data, but most models registered values between $10 \%$ to $15 \%$. The model IPSL-CM5A-LR showed a value above $20 \%$ and the models ACCESS1.0, EC-EARTH and MRI-CGCM3 showed values that were very near to those observed, with values of $9.1 \%, 8.0 \%$ and $6.8 \%$, respectively.

The correlation coefficients were significant and had high values in only six of the models under study, namely: ACCESS1-0, CanESM2M, EC-EARTH, GFDL-CM3, MIROC5 and MRI-CGCM3, with absolute correlations above 0.6 for the first component and between 0.27 and 0.38 for the second component. Only MRI-CGCM3 and ACCESS1.0, however, showed a direct relationship with the observed data, with a positive correlation coefficient for both components.

Table 3: Captured Variance and correlation coefficient between the main components of the CMIP5 Models and the observed components. $(*)$ represents $95 \%$ statistically significant correlations.

\begin{tabular}{lllll}
\hline Models & Explained Variance & & Correlation & PC2 \\
\hline ACCESS1.0 & PC1 & PC2 & PC1 & $\mathbf{0 . 2 7}(*)$ \\
CanESM2M & $\mathbf{2 9 , 2 \%}$ & $9,1 \%$ & $\mathbf{0 , 6 7}\left({ }^{*}\right)$ & $\mathbf{0 . 3 8}\left(^{*}\right)$ \\
CCSM4 & $\mathbf{3 3 , 5 \%}$ & $\mathbf{1 1 , 6 \%}$ & $\mathbf{0 , 6 8}\left(^{*}\right)$ & 0,05 \\
\hline
\end{tabular}




\begin{tabular}{|c|c|c|c|c|}
\hline CNRMCM5 & $32,2 \%$ & $12,0 \%$ & 0,08 & 0,10 \\
\hline GFDL-ESM2M & $19,6 \%$ & $10,4 \%$ & 0,10 & 0,08 \\
\hline INMCM4 & $31,5 \%$ & $13,0 \%$ & 0,06 & 0,03 \\
\hline HadGEM2.ES & $31,4 \%$ & $13,6 \%$ & 0,05 & 0,12 \\
\hline MIROC.ESM & $28,6 \%$ & $15,7 \%$ & 0,14 & 0,04 \\
\hline MPI-ESM-LR & $20,6 \%$ & $13,3 \%$ & 0,17 & 0,10 \\
\hline NorESM1M & $35,9 \%$ & $17,9 \%$ & 0,07 & 0,05 \\
\hline EC-EARTH & $9,3 \%$ & $8,0 \%$ & $0,72\left(^{*}\right)$ & $0,35\left(^{*}\right)$ \\
\hline GFDL-CM3 & $32,2 \%$ & $12,9 \%$ & $0,78\left(^{*}\right)$ & $0,36(*)$ \\
\hline IPSL-CM5A-LR & $31,7 \%$ & $21,3 \%$ & 0,14 & 0,03 \\
\hline MIROC5 & $23,0 \%$ & $13,7 \%$ & $0,66(*)$ & $0,38(*)$ \\
\hline MRI-CGCM3 & $25,5 \%$ & $6,8 \%$ & $0,73(*)$ & $0,27(*)$ \\
\hline CSIRO-mk3 & $27,6 \%$ & $17,4 \%$ & $-0,03$ & 0,02 \\
\hline
\end{tabular}

The Fig. 4 shows the spatial patterns of the principal components of the CMIP5 models, whose correlation coefficients were statistically significant at 99\%. The models CanESM2M, EC-EARTH, GFDL-CM3, MIROC5 represented the two principal cores observed in the PC1 of the observed data, but the signals were opposed. The models that best represented the spatial pattern of the observed data were the ACCESS1-0 and MRI-CGCM3 models, since they were the only ones that had a positive correlation coefficient for the first component and a captured variance close to the observed values.

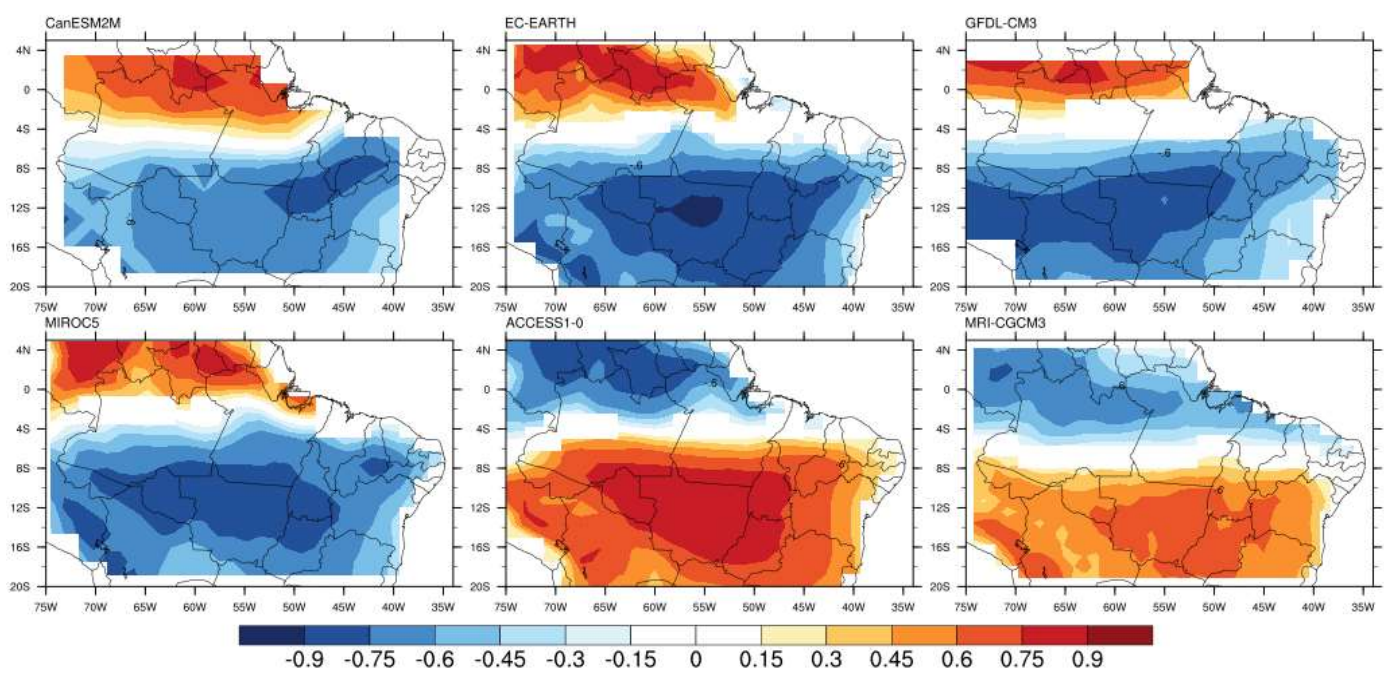

Figure 4: Correlation coefficient between PC1 and rainfall data simulated by CMIP5 models.

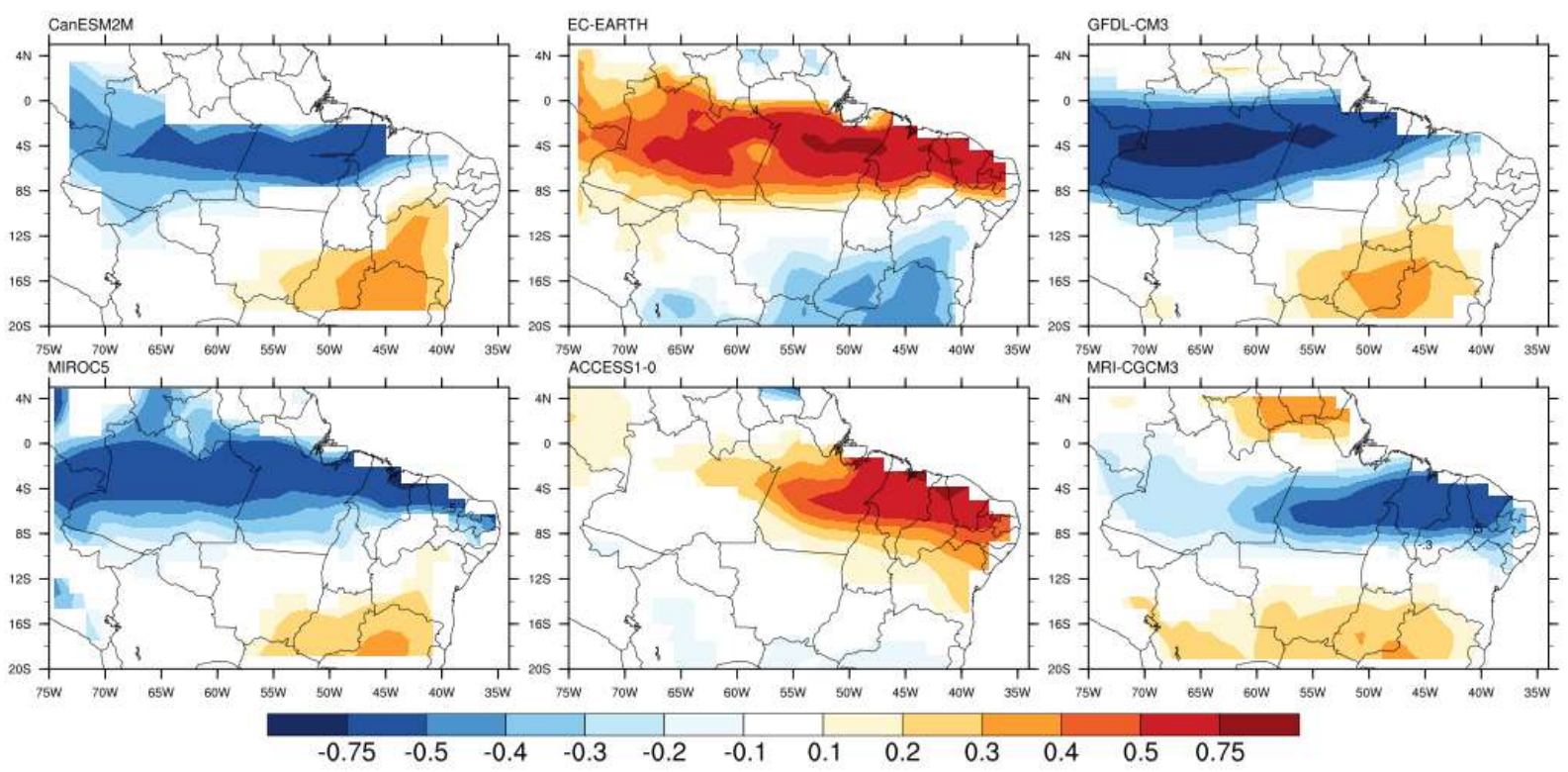

Figure 5: Correlation coefficient between PC2 and rainfall data simulated by CMIP5 models. 
The spatial patterns of the second component are presented in Fig. 5, the representation in this way, by the models, showed a greater difference when compared to the observed. The CanESM2M, GFDL-CM5 models, show the nucleus over the Northeast displaced to the Amazon, and the nucleus located over the Southeast with displacement in the north direction. The models EC-EARTH MIROC e MRI-CGCM3, show the nucleus on the NEB, however they show expansion towards the Amazon, the nucleus with opposite sign located on the southeast also shows an expansion in the north direction, this difference of sensitivity to the second mode can be observed in the correlations of the Table 3, because in this mode the greatest correlation observed was 0.38 , confirming the difficulty of the models in characterizing this pattern of precipitation.

\section{DISCUSSION}

The precipitation regime over $\mathrm{TBr}$ is influenced by various meteorological systems, such as the Intertropical Convergence Zone (ITCZ), the South Atlantic Convergence Zone (SACZ), Lines of Instabilities (LI), Sea Breezes and Mesoscale Convective Complexes, front systems, and also by radiative heating (LIEBMANN et al., 2011; REBOITA et al., 2010). These systems modulate the intensity of precipitation over TBr. Among them, the two with the most pronounced effect between December and May are the SACZ and ITCZ, both with the large scale dominant cycles.

The performance of sixteen CMIP5 models in simulating the weekly precipitation pattern over Tropical Brazil was evaluated and compared with the data observed in the grid points of CPC-uni/NOAA. In the first step, the ability of the model to simulate the frequency distribution was assessed. The models that best represented the regional pattern at this stage were the MIROC5, CNRMCM5, and HadGEM2-ES models. NNEB was the region with the largest disparities, with models tending to underestimate weak rain and overestimates the other classes of rainfall.

The Taylor diagram evaluation revealed that, in general, the models had the same dispersion pattern. The regions NNEB and SNEB had the worse representation and the model INMCM4 stood out because of the high discrepancy in relation to the observed data, low correlation and a high value of the ratio with CPC-uni for all regions.

The PCA of the observed data revealed that the first two components capture approximately $30 \%$ of the variability in precipitation. The associated patterns are quite distinct. In the first mode the core covers the entire south sector of the AMZ and south of NEB with a contrary signal to the far north of the AMZ. The second component of observed data demonstrates a characteristic associated with the Intertropical Convergence Zone, with a signal over the North of the Northeast and East of the Amazon.

The PCA applied to the models revealed that only six models (ACCESS1- 0, CanESM2M, EC-earth, GFDL-CM3, MIROC5 and MRI-CGCM3) were capable of representing the spatial-temporal precipitation pattern, despite the discrepancies related to the temporal signal, demonstrated by the correlation signal between the observed data and those simulated by the models. The spatial response, however, was consistent. In general, the MRI-CGCM3 model was able to capture the spatial pattern and the temporal correlation of the variability in relation to the frequency distribution and the Taylor diagram. This model 
showed a regular response, even considering the regions with less sensitivity to the simulations, such as NNEB and SNEB. Other studies are needed to investigate the interannual and decadal signal, in addition to the patterns associated with future scenarios until the end of the 21st century.

\section{CONCLUSIONS}

We conclude that the CMIP5 models do not have sensitivity to capture the observed precipitation values on $\mathrm{TBr}$, on the other, the signal (trend) models can capture. In the Amazon Basin, the models underestimate the CMIP5 precipitation, especially during the dry season.

The spatial pattern of precipitation by CMIP5 models is very distracting, not getting in sometimesseasonal variability that occurs between the rainy and dry season on the TBr. As a result, the CMIP5 models fail to capture the variability over Brazil Tropical in wet months, largely due not representing meteorological systems that influence this region.

ACKNOWLEDGEMENTS: NJC Barreto were supported by Foundation CAPES (PhD scholarschips CAPES-DS).

\section{REFERENCES}

BARRETO, N. J. C.; MENDES, D.; LUCIO, P. S.. Avaliação Preliminar da Sensibilidade dos Modelos Do CMIP5 a Precipitação Sazonal do Brasil Tropical. Revista Brasileira de Geografia Física, v.6, n.4, p.873-887, 2013a.

BARRETO, N. J. C.; MENDES, D.; LUCIO, P. S.. Comparação entre os modelos de cmip5 e a climatologia da precipitação semanal sobre o Brasil Tropical. Revista Ciência e Natura, n.2013, p.353-355, 2013b.

BARRETO, N. J. C. N. J. C.; MESQUITA, M. D. S.; MENDES, D.; SPYRIDES, M. H. C.; PEDRA, G. U.; LUCIO, P. S.. Maximum covariance analysis to identify intraseasonal oscillations over tropical Brazil. Climate Dynamics, v.49, n.5-6, p.1589-1596, 2017. DOI: http://doi.org/10.1007/s00382-016-3401-3

CARVALHO, L. M. V.; JONES, C.. CMIP5 Simulations of LowLevel Tropospheric Temperature and Moisture over the Tropical Americas. Journal of Climate, v.26, n.17, p.62576286, 2013.

CHEN, M.; SHI, W.; XIE, P.; XILSA, V. C. B.; KOUSKY, V. E.; HIGGINS, W.; JANOWIAK, J. E.. Assessing objective techniques for gauge-based analyses of global daily precipitation. Journal of Geophysical Research, v.113, n.D4, p.04110, 2008. DOI: http://doi.org/10.1029/2007JD009132

COX, P. M.; BETTA, R. A.; COLLINS, M.; HARRIS, P. P. I.. The role of ecosystem-atmosphere interactions in simulated Amazonian precipitation decrease and forest dieback under global climate warming. Theoretical and Applied Climatology, v.78, n.1-3, 2004. DOI: http://doi.org/10.1007/s00704-004-0050-y

FIELD, C. B.; BEHRENFELD, M. J.; RANDERSON, J. T.; FALKOWSKI, P.. Primary production of the biosphere: integrating terrestrial and oceanic components. Science, New York, v.281, n.5374, p.237-40, 1998. DOI: http://doi.org/10.1126/science.281.5374.237

GONZALEZ, R. A.; ANDREOLI, R. V.; CANDIDO, L. A.; KAYANO, M. T.; SOUZA, R. A. F.. A influência do evento El Niño Oscilação Sul e Atlântico Equatorial na precipitação sobre as regiões norte e nordeste da América do Sul. Acta Amazônica, v.43, n.4, p.469-480, 2007. DOI: http://dx.doi.org/10.1590/S0044-59672013000400009

KOUADIO, Y. K.; LENTINI, C. A. D.; KOUADIO, Y. K.; SERVAIN, J.; MACHADO, L. A. T.. Heavy rainfall episodes in the eastern northeast Brazil linked to large-scale ocean-atmosphere conditions in the tropical atlantic. Advances in Meteorology, v.2012, p.1-16, 2012.

KROL, M. S.; BRONSTERT, A.. Regional integrated modelling of climate change impacts on natural resources and resource usage in semi-arid Northeast Brazil. Environmental Modelling \& Software, v.22, n.2, p.259-268, 2007.

LI, W.; FU, R.; DICKINSON, R. E.. Rainfall and its seasonality over the Amazon in the 21st century as assessed by the coupled models for the IPCC AR4. Journal of Geophysical Research, v.111, n.D2, p.D02111, 2006.

LIEBMANN, B.; KILADIS, G. N.; ALLURED, D.; VERA, C. S.; JONE, S. C.; CARVALHO, L. M. V.; BLADÉ, I.; GONZÁLES, P. L. M.. Mechanisms Associated with Large Daily Rainfall Events in Northeast Brazil. Journal of Climate, v.24, n.2, p.376-396, 2011. DOI: https://doi.org/10.1175/2010JCLI3457.1

MALMGREN, B. A.; WINTER, A.. Climate zonation in Puerto Rico based on principal components analysis and an artificial neural network. Journal of Climate, v.12, n.4, p.977-985, 1999.

MARENGO, J. A.. Interdecadal variability and trends of rainfall across the Amazon basin. Theoretical and Applied 
Climatology, v.78, n.1-3, p.79-96, abr. 2004

MARENGO, J. A.; NOBRE, C. A.; TOMASELLA, J.; OYAMA, M. D.; OLIVEIRA, G. S.; OLIVEIRA, R.; CAMARGO, H.; ALVES, L. M.; BROWN, F. I.. The drought of Amazonia in 2005. Journal of Climate, v.21, n.3, p.495-516, 2008. DOI: https://doi.org/10.1175/2007JCLI1600.1

MARENGO, J. A.; VALVERDE, M. C.. Caracterização do clima no Século XX e Cenário de Mudanças de clima para o Brasil no Século XXI usando os modelos do IPCC-AR4. Revista Multiciência, v.8, p.5-28, 2007.

OYAMA, M. D.; NOBRE, C. A.. Climatic consequences of a large-scale desertification in northeast Brazil: a GCM simulation study. Journal of Climate, v.17, n.16, p.32033213, 2004.

PEÑARROCHA, D.; ESTRELA, M. J.; MILLÁN, M.. Classification of daily rainfall patterns in a Mediterranean area with extreme intensity levels: the Valencia region. International Journal of Climatology, v.22, n.6, p.677-695, 2002.

RAO, V.; HADA, K.. Characteristics of rainfall over Brazil: annual variations and connections with the southern oscillation.Theoretical and applied climatology, v.42, n.2, p.81-91, 1990.

REBOITA, M. S.; GAN, M. A.; ROCHA, R. P.; AMBRIZZI, T.. Precipitation regimes in South America: a bibliography review. Revista Brasileira de Meteorologia, v.25, n.2, p.185204, 2010. DOI: http://doi.org/10.1590/S010277862010000200004

SABEERALI, C. T.; DANDI, R.; DHAKATE, A. R.; MAHAPATRA, S.; RAO, S. A.. Simulation of boreal summer intraseasonal oscillations in the latest CMIP5 coupled GCMs. Journal of Geophysical Research: Atmospheres, v.118, n.10, p.44014420, 2013. DOI: http://doi.org/10.1002/igrd.50403

SILVA, V. B. S.; KOUSKY, V. E.; HIGGINS, R. W.. Daily Precipitation Statistics for South America: An Intercomparison between NCEP Reanalyses and Observations. Journal of Hydrometeorology, v.12, n.1, p.101-117, 2011.

SILVEIRA, C. S.; SOUZA FILHO, F. A; LÁZARO, Y. M. C.; COST, A. A.; SALES, D. C.; COUTINHO, M. M.. Sazonalidade da Precipitação Sobre o Nordeste Setentrional Brasileiro nas Simulações do IPCC-AR4. Revista Brasileira de Recursos Hídricos, v.17, n.3, p.125-134, 2012.

SILVEIRA, C. S.; SOUZA FILHO, F. A.; LÁZARO, Y. M. C.. Avaliação de Desempenho dos Modelos de Mudança Climática do IPCC-AR4 Quanto a Sazonalidade e os Padrões de Variabilidade Interanual da Precipitação Sobre o Nordeste do Brasil, Bacia do Prata e Amazônia. Revista Brasileira de Recursos Hídricos, v.18, n.1, p.177-194, 2013.

SOUZA, E. B.; KAYANO, M. T.; AMBRIZZI, T.. The regional precipitation over the eastern Amazon/northeast Brazil modulated by tropical pacific and Atlantic SST anomalies on weekly timescale. Revista Brasileira de Meteorologia, v.19, n.2, p.113-122, 2004.

SOUZA, E. B.; AMBRIZZI, T.. Modulation of the intraseasonal rainfall over tropical Brazil by the Madden-Julian oscillation.International journal of climatology, v.26, n.13, p.1759-1776, 2006.

TAYLOR, J. W.. An evaluation of methods for very short-term load forecasting using minute-by-minute British data. International Journal of Forecasting, v.24, n.4, p.645-658, 2008.

TAYLOR, K. E.; STOUFFER, R. J.; MEEHL, G. A.. An overview of CMIP5 and the experiment design.Bulletin of the American Meteorological Society, v.93, n.4, p.485, 2012.

VERA, C.; SILVESTRI, G.; LIEBMANN, B.; GONZÁLEZ, P.. Climate change scenarios for seasonal precipitation in South America from IPCC-AR4 models. Geophysical Research Letters, v.33, n.13, p.L13707, 2006. DOI: https://doi.org/10.1029/2006GL025759

WILKS, D. S.. Statistical methods in the atmospheric sciences. Academic press, 2011.

A CBPC - Companhia Brasileira de Produção Científica (CNPJ: 11.221.422/0001-03) detém os direitos materiais desta publicação. Os direitos referem-se à publicação do trabalho em qualquer parte do mundo, incluindo os direitos às renovações, expansões e disseminações da contribuição, bem como outros direitos subsidiários. Todos os trabalhos publicados eletronicamente poderão posteriormente ser publicados em coletâneas impressas sob coordenação da Sustenere Publishing, da Companhia Brasileira de Produção Científica e seus parceiros autorizados. Os (as) autores (as) preservam os direitos autorais, mas não têm permissão para a publicação da contribuição em outro meio, impresso ou digital, em português ou em tradução. 